\title{
A Forest Growth Dynamic Indicator
}

\author{
Vinicius Leal ${ }^{1}$, Thomaz $\operatorname{Costa}^{2}$ and Andreia Silva ${ }^{3}$ \\ 1. Santo Agostinho Colleges, Sete Lagoas 35700-068, Brazil \\ 2. Core of Water, Soil and Environmental Sustainability (NSAM), Embrapa Maize and Sorghum, Sete Lagoas 35701-970, Brazil \\ 3. Herbarium of PAMG, EPAMIG, Belo Horizonte 31170-495, Brazil
}

\begin{abstract}
The dynamics of forest growth are related to the succession stage, the quality of the environment and the degree of anthropism. The growth of a forest is given by the activity of live trees, mortality, and trees that are cut or recruited during the growing period. A way of representing the growth dynamics of a forest is by the Transition Matrix, with the divisibility of the population in states, with probabilities of movement from one state to another, over time. Forest dynamics studies are carried out by means of a continuous forest inventory, allowing the calculation of gains and losses in basal area, mortality rates and ingrowth. In this study, the measurements were performed with a 5-year interval, on 27 plots distributed in 12 sites. The methodology correlated parameters of the forest dynamics with canopy, soil, relief and hydrographic parameters. An indicator of forest growth dynamics was proposed and it was tested. It was confirmed that the density factor interferes in growth dynamics of the forest.
\end{abstract}

Key words: Transition matrix, index, environmental parameters.

\section{Introduction}

Ecological succession is the process in which vegetation passes to achieve a relative stability in physiological, structural and floristics characteristics [1]. During this process, changes occur in forest communities, called forest dynamics [2]. The species have different growth rates, life cycles, and pioneer species that begin the process, have higher rates of growth and short life cycles [3, 4].

In addition to the genetic feature, species growth is conditioned to the environment, characterized by geographic location, water supply, relief, soil quality (fertility, organic matter, soil depth, among others) [5], justifying that vegetation in tropical forest areas is complex due to the large number of species and the multiple interactions between plants and environment [6].

There is a consensus in the literature that the successional process is complex and may involve a considerable number of biotic and abiotic variables, such as diversity of flora and fauna species, climatic,

Corresponding author: Thomaz Costa, Ph.D., main research field: remote sensing of vegetation. edaphic and anthropic factors [7].

In Brazil, the classification of successional stages in areas of Atlantic Forest is defined by resolutions of the CONAMA (National Environment Council), edited for each State of the Federation (Brasil, 1990, 1993a, 1993b, 2007) apud [7]. However, their applications are not practical and become subjective and imprecise, due to the quantity and subjectivity of parameters involved and the environmental and anthropic variations. In this work, authors choose the distribution of size classes and proportion of successional groups, not to define the succession stages, but to obtain a relative comparison between sites.

The growth of a forest is given by the activity of live trees, mortality [8], and trees that are cut or recruited during the growing period [9]. The gaps are one of the main factors for the natural succession dynamics of tropical forests, due to the natural fall or death of trees [10].

Understanding of the growth of natural forests is not based on the age, but on the dynamics of growth [11]. One way of representing the dimensions of a forest is by diameter classes, because the age is difficult to obtain [12], and because the tree does not express 
potential development, as in planted forests. Thus, the division into stages of development may allow the prediction of future sizes more precisely than the division into age classes [13].

The height could be a variable to represent the dimensions of the forest too, but its measurement is imprecise due to the contact of canopies, difficulty of standardization of the measurement in the same place of canopy, inclination of the wood, among other difficulties, besides being a variable more sensitive to the quality of the forest.

For the adjustment of the distribution of diameters in natural forest the exponential functions in the form of inverted J (Meyer, 1943; Leak, 1964) apud [14] is generally used to express the tree density.

Mathematical functions (linear, polynomial or exponential) are used to represent tree size distributions, but are not appropriate when time series are involved [15], which refers to forest changes or forest dynamics.

A way of representing the growth dynamics of a forest is by the Transition Matrix [16], with the divisibility of the population in states, with probabilities of movement from one state to another, over time [13]. This matrix is used in the simulation and prediction methodology called "Markov Chain", a stochastic process, in which the transition probabilities during the time interval $(t+1)$ depend only on the state of the individual at time $t$, that is, of knowledge of the immediate past at time $t+1$, and not in any other state [17]. "Time invariance" is a characteristic of the Markov Chain [18].

Thus models which use transition matrix are appropriate for growth and increment data of multi-level stands of tropical forests [13, 19].

Forest dynamics studies are carried out by means of a continuous forest inventory. The plots are re-measured after a time interval, allowing calculation of gains and losses in basal area, mortality and ingrowth rates [20-22].

This work proposes to relate the dynamics of fragments of a semideciduous forest with the parameters of forest structure, soil, relief and hydrographics, and propose an index of forest growth dynamics.

\section{Material and Methods}

The study area is the Experimental Farm of Embrapa Milho e Sorgo, located in the city of Sete Lagoas, Minas Gerais, Brazil, in a region with the following vegetation types: Savannah Park, Grassy-Woody Savannah, Savannah Tree, Savannah Woodland, Lowland and Semideciduous Forest and Evergreen Seasonal Forest [23].

The Köppen climate classification is Cwa [24], indicating Savannah climate with dry winters and rainy summers. The average annual temperature is $21.1^{\circ} \mathrm{C} \pm$ $6.0^{\circ} \mathrm{C}$, the average annual rainfall is $1,384 \mathrm{~mm}$ and the average annual potential evapotranspiration is approximately $1,444 \mathrm{~mm} \mathrm{[25].}$

Eight patches of forest physiognomy were selected for this study, characterized by the absence of grass in the understory layer, the presence of straight tree trunks, high canopy, non-coriaceous leaves, not in the early stages of the ecological succession, and at least 50 years old of recovering from pasture.

Twelve sites were selected in these patches (Fig. 1) and 27 plots, $20 \times 20$ meters, were marked in 100 meters from the edge of the patches. The number of sites and plots is proportional to the size of the patches. Patch 1: three sites (11, 12 and 13) with two plots each; Patch 2: one site (21) with three plots; Patch 3: one site (31) with one plot; Patch 4: one site (41) with three plots; Patch 5: two sites (51 and 52) with two plots each; Patch 6: one site (61) with three plots; Patch 7: one site (71) with three plots; and Patch 8: two sites (81 and 82) with two plots each.

The diameter of the trees at $1.3 \mathrm{~m}$ height, or DBH (Diameter at Breast Height) $\geq 5 \mathrm{~cm}$ and the height of the all trees sampled were measured, being the first measurement in 2010 and the second in 2015. Authors used electronic hypsometer to measure height of all trees. 


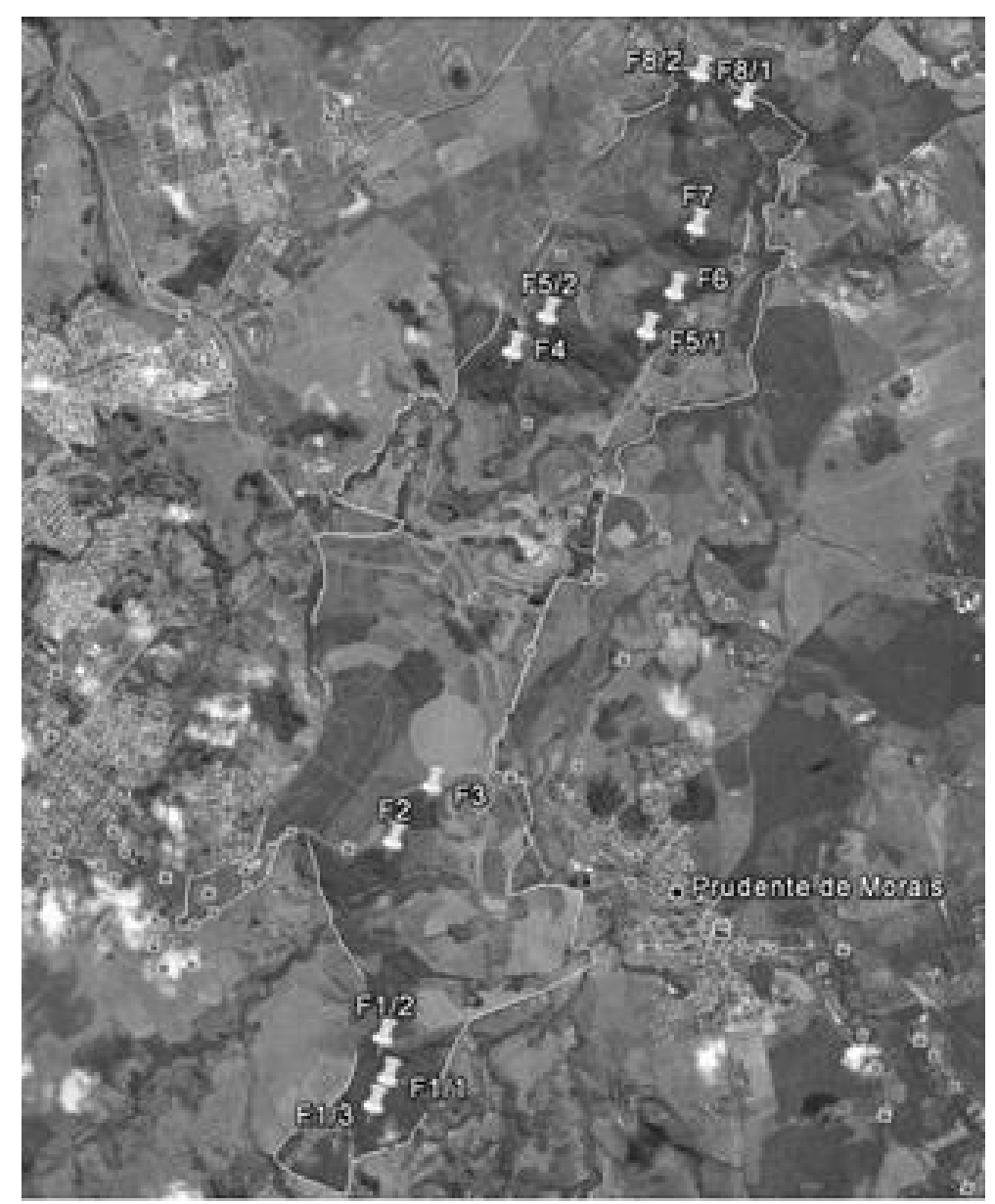

Fig. 1 Location of the sites in each patch (F1/1 to F8/2) on the Experimental Farm of Embrapa, Sete Lagoas, Minas Gerais, Brazil. Source of image: Google Earth, central coordinates 44, 17 W, 19, $44 \mathrm{~S}$.

The botanical collection of material was sent to the PAMG (Epamig Herbarium of Minas Gerais), identified with support of Virtual Herbarium Tropicos.org. and The Field Museum [26, 27], and of the Herbarium Collection of the Agricultural Research Company of Minas Gerais (Epamig), where the species were identified by the APGIII (Angiosperm Phylogeny Group III) Classification System [28, 29]. The confirmation of botanical names with synonymy was supported by Flora do Brasil [10]. And the variables obtained by site were density (D), ind $\cdot \mathrm{m}^{-2}$; basal area (B) in $\mathrm{m}^{2} \cdot \mathrm{ha}^{-1}$; average canopy height, $\mathrm{h}(\mathrm{m})$.

Ingrowth is when the plant exceeds at least the minimum limit of the smallest diameter class approached by the survey, being the process by which the tree arises throughout the temporal process. Mortality is the number of trees that were measured at baseline, which were not cut, and died during the growth period. Mortality and ingrowth rates, basal area gain and loss rates, based on number of individuals and basal area, were calculated using Eq. (1) [22, 30]:

$$
\begin{gathered}
M=\left\{1-\left[\frac{\left(N_{0}-m\right)}{N_{0}}\right]^{1 / t}\right\} * 100 \\
I=\left[1-\left(1-\frac{i}{N t}\right)^{1 / t}\right]^{*} 100 \\
P=\left\{1-\left[\frac{A B_{0}-\left(A B_{m}+A B_{d}\right)}{A B_{0}}\right]^{1 / t}\right\} * 100 \\
G=\left\{1-\left[\left(1-\frac{\left(A B_{i}+A B_{g}\right)}{A B_{t}}\right]^{1 / t}\right\} * 100\right.
\end{gathered}
$$

In which:

$\mathrm{M}=$ annual mortality rate; 
$\mathrm{I}=$ annual ingrowth rate;

$\mathrm{P}=$ loss rate in annual basal area;

$\mathrm{G}=$ rate of gain in annual basal area;

$\mathrm{t}=$ time interval between inventories;

No = initial number of trees;

$\mathrm{Nt}=$ number of surviving trees on $\mathrm{t}$;

$\mathrm{M}=$ number of dead trees;

$\mathrm{i}=$ number of trees ingrowthed;

$\mathrm{ABo}=$ initial basal area;

$\mathrm{ABt}=$ basal area after $\mathrm{t}$;

$\mathrm{ABm}=$ basal area of dead trees;

$\mathrm{ABd}=$ loss in basal area (diameter reduction and partial loss of trunks);

$\mathrm{ABr}=$ basal area of treeingrowth;

$\mathrm{ABg}=$ basal area gain (tree growth).

After the five-year period, the function proposed by Meyer, H. A. [31] was applied to estimate the J-inverted equation, and to characterize the diametric structure:

$$
Y_{j}=e^{b_{0}+b_{1} D_{j}}
$$

where

$Y_{j}=$ estimator of the number of trees per hectare in the class $\mathrm{j}$ of DAP;

$b_{0}$ and $b_{1}=$ coefficients of the equation;

$D_{j}=$ diameter corresponding to the center of the class $\mathrm{j}$ of DAP;

$\mathrm{e}=$ constant of Naperian logarithms.

The transition matrix in the five-year period in each site was used to calculate the forest growth indicator, using the frequency of trees per state (diameter classes with a $2 \mathrm{~cm}$ interval). This indicator used the parameters of mortality, ingrowth, passage and no change of state of the trees. Its expression is given by:

$$
I \text { Growth }=\frac{(\text { ingrowth }+ \text { passage })}{(\text { mortality 2015 }}
$$

It is assumed that its value indicates that the more productive the environment, the higher the indicator. That is, the higher the frequency of trees entering the first diameter classes, that cross to larger diameter classes between 2010 and 2015, the lower the mortality occurred between 2010 and 2015, and the lower the frequency of trees that did not change between 2010 and 2015, the greater the dynamics of forest growth.

In order to explore the relationship of growth with the environments of semideciduous forest fragments (patches) in different natural and anthropogenic conditions, principal component analysis was used to analyze the magnitude of the correlation and direction of each variable, identifying the behavior of the variables depending on objective.

\section{Results}

In 2010, 1.227 individuals were sampled, belonging to 136 species distributed in 42 families. In 2015, 1.344 individuals belonging to 143 species were sampled in the same 42 families, with 113 individuals dead and 116 entering. The families that presented the largest number of individuals, in 2010 and 2015, were Fabaceae, Rubiaceae, Myrtaceae, Sapindaceae and Meliaceae, representing $53.28 \%$ of the individuals sampled.

The most abundant species were Cordiera sessilis (Vell.) Kuntze (5.13\%), followed by Protium heptaphyllum (Aubl.) Marchand with 4.91\%, Dilodendron bipinnatum Radlk with $4.61 \%$ and Swartzia multijuga Vogel with $4.46 \%$. Table 1 shows the tree species.

Fig. 2 shows the probability of occurrence of the species of Table 1 (by site) in the typologies of the Atlantic Forest (pB, pC, pD), of the Savannah (pA), and the Seasonal always green forest $(\mathrm{pE})$. The majority probability, in general, occur in always green forest, followed by the Savannah, Semideciduous Forest, Deciduous Forest, and the lowest probabilities for Tropical rain forest. This characterizes ecotone environments, the transitional Atlantic Forest biome opportunely installed in the Savannah biome in the form of spots, due to the proximity of bodies of water, configuration of the relief, contributing in the humidity, and the propitious condition of the soils, especially the depth of them. 
Table 1 Species sampled in 2015.

\begin{tabular}{|c|c|c|c|}
\hline Family & Species & N. Indiv. & N. Indiv. \\
\hline \multirow[t]{5}{*}{ Anacardiaceae } & Astronium fraxinifolium Schott & 1 & 68 \\
\hline & Astronium graveolens Jacq. & 18 & \\
\hline & Lithrea molleoides (Vell.) Engl. & 2 & \\
\hline & Myracrodruon urundeuva Allemão & 46 & \\
\hline & Tapirira guianensis Aubl. & 1 & \\
\hline \multirow[t]{3}{*}{ Annonaceae } & Annona dolabripetala Raddi & 23 & 68 \\
\hline & Annona sylvatica A.St.-Hil. & 44 & \\
\hline & Xylopia aromatica (Lam.) Mart. & 1 & \\
\hline \multirow[t]{3}{*}{ Apocynaceae } & Aspidosperma cylindrocarpon Müll. Arg. & 2 & 14 \\
\hline & Aspidosperma spruceanum Benth. Ex Müll.Arg. & 2 & \\
\hline & Aspidosperma subincanum Mart. & 10 & \\
\hline \multirow[t]{3}{*}{ Araliaceae } & Aralia warmingiana (Marchal) J.Wen & 2 & 5 \\
\hline & Dendropanax cuneatus (DC.) Decne. \& Planch. & 1 & \\
\hline & Schefflera morototoni (Aubl.) Maguire et al. & 2 & \\
\hline Arecaceae & Acrocomia aculeata (Jacq.) Lodd. ex Mart. & 6 & 6 \\
\hline Asteraceae & Vernonanthura polyanthes (Sprengel) Vega \& Dematteis & 1 & 1 \\
\hline \multirow[t]{4}{*}{ Bignoniaceae } & Handroanthus serratifolius (Vahl) S.Grose & 3 & 9 \\
\hline & Jacaranda macrantha Cham. & 1 & \\
\hline & Tabebuia roseoalba (Ridl.) Sandwith & 4 & \\
\hline & Undetermined & 1 & \\
\hline Burseraceae & Protium heptaphyllum (Aubl.) Marchand & 66 & 66 \\
\hline \multirow[t]{3}{*}{ Cannabaceae } & Celtis iguanaea (Jacq.) Sarg. & 1 & 4 \\
\hline & Celtis pubescens (Kunth) Spreng. & 1 & \\
\hline & Trema micrantha (L.) Blume & 2 & \\
\hline Cardiopteridaceae & Citronella cf.paniculata (Mart.) R.A.Howard & 1 & 1 \\
\hline Celastraceae & Maytenus floribunda Reissek & 24 & 24 \\
\hline \multirow[t]{2}{*}{ Chrysobalanaceae } & Hirtella gracilipes (Hook.f.) Prance & 4 & 6 \\
\hline & Licania sp. & 2 & \\
\hline Clusiaceae & Calophyllum brasiliense Cambess. & 1 & 1 \\
\hline Combretaceae & Terminalia glabrescens Mart. & 16 & 16 \\
\hline Cunoniaceae & Lamanonia ternata Vell. & 1 & 1 \\
\hline \multirow[t]{2}{*}{ Ebenaceae } & Diospyros hispida A.DC. & 33 & 54 \\
\hline & Diospyros inconstans Jacq. & 21 & \\
\hline Erythroxylaceae & Erythroxylum daphnites Mart. & 1 & 1 \\
\hline \multirow[t]{2}{*}{ Euphorbiaceae } & Alchornea glandulosa Poepp. \& Endl. & 3 & 9 \\
\hline & Gymnanthes klotzschiana Müll.Arg. & 6 & \\
\hline \multirow[t]{12}{*}{ Fabaceae } & Albizia niopoides (Spruce ex Benth.) Bukart & 1 & 288 \\
\hline & Albizia polycephala (Benth.) Killip. ex Record & 2 & \\
\hline & Albizia sp. & 1 & \\
\hline & Anadenanthera colubrina var.cebil (Griseb.) Altschul & 20 & \\
\hline & Anadenanthera peregrina (L.) Speg. & 2 & \\
\hline & Anadenanthera sp. & 2 & \\
\hline & Andira fraxinifolia Benth. & 1 & \\
\hline & Bauhinia longifolia (Bong.) Steud. & 19 & \\
\hline & Cassia ferruginea (Schrad.) Schrad ex DC. & 1 & \\
\hline & Chamaecrista ensiformis (Vell.) H.S.Irwin \& Barneby & 27 & \\
\hline & Copaifera langsdorffii Desf. & 47 & \\
\hline & Dalbergia foliolosa Benth. & 1 & \\
\hline
\end{tabular}


Table 1 to be continued

\begin{tabular}{|c|c|c|c|}
\hline \multirow[t]{26}{*}{ Fabaceae } & Dalbergia miscolobium Benth. & 1 & \\
\hline & Hymenaea courbaril $\mathrm{L}$. & 4 & \\
\hline & Inga marginata Willd. & 1 & \\
\hline & Inga vera subsp.affinis (DC.) T.D.Penn. & 14 & \\
\hline & Lonchocarpus sp. & 1 & \\
\hline & Machaerium aculeatum Raddi & 2 & \\
\hline & Machaerium acutifolium Vogel & 1 & \\
\hline & Machaerium cf.villosum Vogel & 3 & \\
\hline & Machaerium hirtum (Vell.) Steelfeld & 1 & \\
\hline & Machaerium stipitatum Vogel & 25 & \\
\hline & Machaerium sp. & 4 & \\
\hline & Peltophorum dubium (Spreng.) Taub. & 1 & \\
\hline & Plathymenia reticulada Benth. & 5 & \\
\hline & Platycyamus regnellii Benth. & 2 & \\
\hline & Platymiscium pubescens Micheli & 1 & \\
\hline & Platypodium elegans Vogel & 11 & \\
\hline & Senegalia polyphylla (DC.) Britton \& Rose & 4 & \\
\hline & Senna macranthera (DC. ex Collad.) H.S.Irwin \& Barneby & 1 & \\
\hline & Senna sp. & 3 & \\
\hline & Swartzia apetala Raddi & 2 & \\
\hline & Swartzia multijuga Vogel & 60 & \\
\hline & Swartzia pilulifera Benth. & 3 & \\
\hline & Swartzia sp. & 1 & \\
\hline & Sweetia fruticosa Spreng. & 7 & \\
\hline & Zollernia ilicifolia (Brongn.) Vogel & 5 & \\
\hline & Undetermined & 1 & \\
\hline \multirow[t]{3}{*}{ Lamiaceae } & Aegiphila verticillata Vell. & 2 & 7 \\
\hline & Vitex polygama Cham. & 3 & \\
\hline & Vitex sp. & 2 & \\
\hline \multirow[t]{5}{*}{ Lauraceae } & Nectandra membranacea (Sw.) Griseb & 2 & 26 \\
\hline & Nectandra oppositifolia Nees & 3 & \\
\hline & Ocotea pulchella (Nees\& Mart.) Mez & 1 & \\
\hline & Ocotea velutina (Nees) Rohwer & 19 & \\
\hline & Undetermined & 1 & \\
\hline Lecythidaceae & Cariniana estrellensis (Raddi) Kuntze & 1 & 1 \\
\hline \multirow[t]{6}{*}{ Malvaceae } & Apeiba tibourbou Aubl. & 1 & 26 \\
\hline & Eriotheca gracilipes (K.Schum.) A.Robyns & 1 & \\
\hline & Guazuma ulmifolia Lam. & 18 & \\
\hline & Helicteres brevispira A.St.-Hil. & 2 & \\
\hline & Luehea grandiflora Mart. \& Zucc. & 2 & \\
\hline & Pseudobombax tomentosum (Mart. \& Zucc.) A.Robyns & 2 & \\
\hline \multirow[t]{6}{*}{ Meliaceae } & Cedrela fissilis Vell. & 3 & 76 \\
\hline & Guarea kunthiana A.Juss. & 9 & \\
\hline & Trichilia catigua A.Juss. & 5 & \\
\hline & Trichilia claussenii C.DC. & 10 & \\
\hline & Trichilia pallida Sw. & 22 & \\
\hline & Trichilia silvatica C.DC. & 27 & \\
\hline Monimiaceae & Mollinedia widgrenii A.DC. & 1 & 1 \\
\hline \multirow[t]{2}{*}{ Moraceae } & Ficus sp. & 1 & 2 \\
\hline & Maclura tinctoria (L.) D. Donex Steud. & 1 & \\
\hline
\end{tabular}


Table 1 to be continued

\begin{tabular}{|c|c|c|c|}
\hline \multirow[t]{9}{*}{ Myrtaceae } & Calyptranthes sp. & 1 & 103 \\
\hline & Eugenia dysenterica DC. & 2 & \\
\hline & Eugenia florida DC. & 40 & \\
\hline & Myrcia sp. & 1 & \\
\hline & Myrcia sp.1 & 2 & \\
\hline & Myrcia splendens (Sw.) DC. & 14 & \\
\hline & Myrcia tomentosa (Aubl.) DC. & 31 & \\
\hline & Myrcia riafloribunda (H.WestexWilld.) O.Berg & 2 & \\
\hline & Undetermined & 10 & \\
\hline Nyctaginaceae & Guapira opposita (Vell.) Reitz & 3 & 3 \\
\hline Ochnaceae & Ouratea castaneifolia (DC.) Engl. & 2 & 2 \\
\hline Oleaceae & Chionanthus trichotomus (Vell.) P.S.Green & 1 & 1 \\
\hline Phyllanthaceae & Hyeronima alchorneoides Allemão & 5 & 5 \\
\hline Polygonaceae & Coccoloba $\mathrm{sp}$ & 1 & 1 \\
\hline Rhamnaceae & Rhamnidium elaeocarpum Reissek & 3 & 3 \\
\hline \multirow[t]{10}{*}{ Rubiaceae } & Chomelia cf.spinosa Jacq. & 1 & 117 \\
\hline & Chomelia obtusa Cham. \& Schlecht. & 1 & \\
\hline & Cordiera sessilis (Vell.) Kuntze & 69 & \\
\hline & Coussarea hydrangeifolia (Benth.) Müll.Arg. & 3 & \\
\hline & Coutarea hexandra (Jacq.) K.Schum. & 10 & \\
\hline & Faramea hyacinthina Mart. & 3 & \\
\hline & Guettarda viburnoides Cham. \& Schltdl. & 8 & \\
\hline & Ixora cf.brevifolia Benth. & 1 & \\
\hline & Ixora gardneriana Benth. & 20 & \\
\hline & Rudgea viburnoides (Cham.) Benth. & 1 & \\
\hline \multirow[t]{5}{*}{ Rutaceae } & Citrus sp. & 1 & 54 \\
\hline & Esenbeckia febrifuga (A.St.-Hil.) A.Juss. ex Mart. & 2 & \\
\hline & Galipea jasminiflora (A.St.-Hil.) Engl. & 38 & \\
\hline & Metrodorea stipularis Mart. & 11 & \\
\hline & Zanthoxylum petiolare A.St.-Hil. \& Tul. & 2 & \\
\hline \multirow[t]{3}{*}{ Salicaceae } & Casearia cf.guianensis (Aubl.) Urb. & 10 & 38 \\
\hline & Casearia decandra Jacq. & 3 & \\
\hline & Casearia sylvestris Sw. & 25 & \\
\hline \multirow[t]{5}{*}{ Sapindaceae } & Allophylus sericeus Radlk. & 1 & 82 \\
\hline & Cupania vernalis Cambess. & 17 & \\
\hline & Dilodendron bipinnatum Radlk. & 62 & \\
\hline & Matayba guianensis Aubl. & 1 & \\
\hline & Matayba sp. & 1 & \\
\hline Sapotaceae & Chrysophyllum marginatum (Hook. \& Arn.) Radlk. & 2 & 2 \\
\hline Siparunaceae & Siparuna guianensis Aubl. & 12 & 12 \\
\hline \multirow[t]{2}{*}{ Urticaceae } & Cecropia glaziovii Snethl. & 4 & 16 \\
\hline & Cecropia pachystachya Trécul & 12 & \\
\hline Verbenaceae & Aloysia virgata (Ruiz \&Pav.) Juss. & 7 & 7 \\
\hline \multirow[t]{3}{*}{ Vochysiaceae } & Callisthene major Mart. \& Zucc. & 9 & 11 \\
\hline & Qualea grandiflora Mart. & 1 & \\
\hline & Vochysia tucanorum Mart. & 1 & \\
\hline Died & & & 96 \\
\hline Not founded & & & 5 \\
\hline Undetermined & & & 5 \\
\hline Total & & & 1344 \\
\hline
\end{tabular}




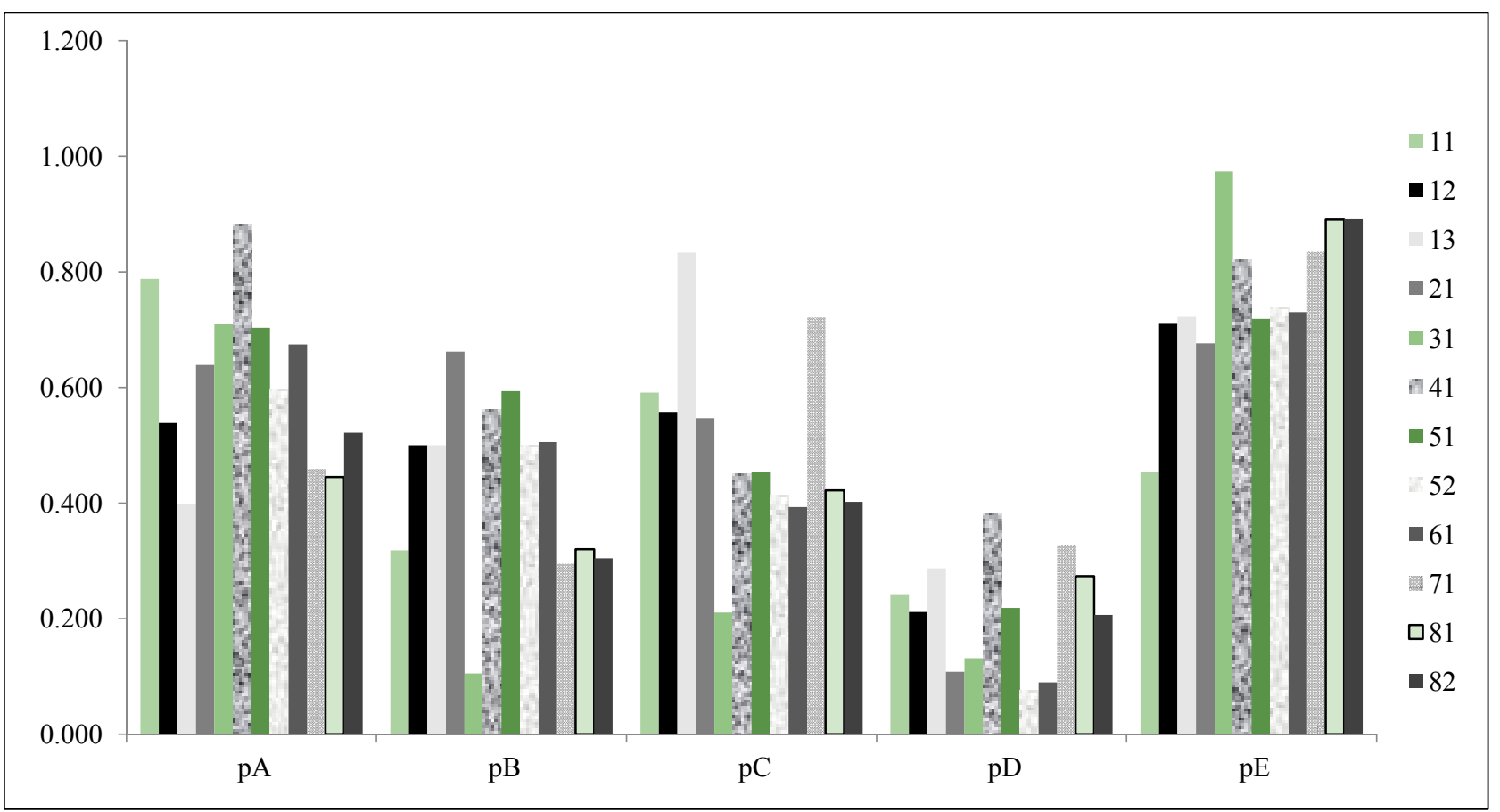

Fig. 2 Probabilistic classification of the 12 sites on phytogeographic system. $A=($ Savannah $), B=($ deciduous seasonal forest $)$, $\mathrm{C}=$ (semideciduous seasonal forest), $\mathrm{D}=$ (tropical rain forest), $\mathrm{E}=$ (seasonal forest always green). Source: Ref. [32].

In order to understand the differences in the growth dynamics conditioned to the growth stage, the diametric distributions and the successional ecology of the species were used.

The diametric distributions and successional ecology are in Figs. 3 and 4, respectively. The trend of inverted J was observed in most sites. Smaller distributions are found in 12,13,21 and 41 sites, ending with trees close to 30 centimeters in diameter. The sites with the widest distributions are 51, 61, 71, 81 and 82 , and the intermediate sites are 11, 31 and 52 .

The relation of the size distribution to the proportion of species in ecological groups was not as expected. Site 31 is a remnant in a more advanced stage than environment 11, but in both results, their curves have similar amplitude, with very low proportions of pioneers, varying little between initial and late secondary species. Sites $21,41,81$ and 82 showed compatibility between the results. The differences in environmental characteristics, with parameters of soil, relief, hydrography, that characterize each environment, interfere in the development cycle of species.

The parameters of canopy, relief, hydrography and soil (Tables 3, 4, 5, 6 and 7) were used [33]. In the evaluation of the canopy, the sites with the largest leaf area (Lai) were $31,82,81,41,52$, the lowest density of trees was 71 , with the lowest basal area were 11, 12, 13 and 71 . The lower diversity and the greater species dominance were significant in the site 13 .

Regarding the relief parameters, the sites with the lowest slope are 11, 13, 21, 31, 81, 82. And the indicators of water proximity (DstWat, ElevWat) show that $41,51,52,61$ and 71 sites have a lower chance of water supply from subsurface zone [33], although sites 41, 52 and 71 are in concave regions with drainage convergences and higher humidity.

Considering the soil parameters, the sites 11, 13 and 71 , even with canopy parameters indicating a condition unfavorable, present higher levels of fertility in horizon A.

The 21, 61 and 81 sites have less favorable fertility characteristics. The site 21 is on a Typic Haplustox [34] (weathered soil with low cation exchange capacity), site 61 is on Humic Haplustox and site 81 is on Humic Haplustox (soils with low base saturation). One factor that differentiates sites 61 and 81 is the presence of 
11

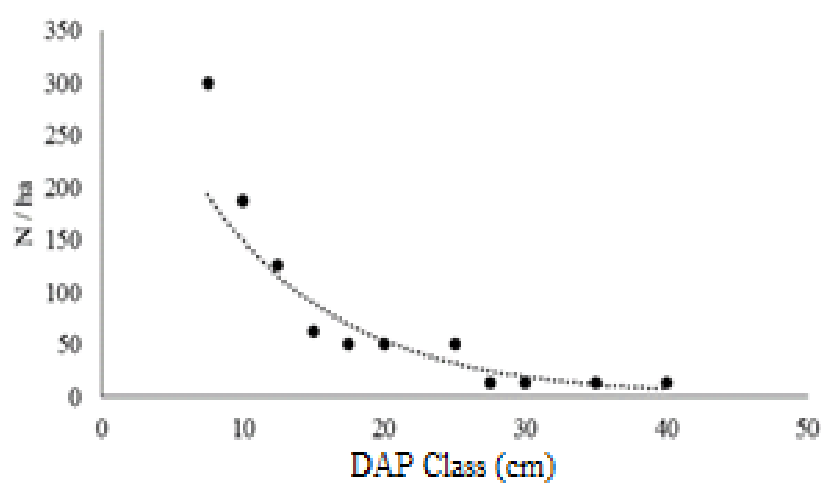

13

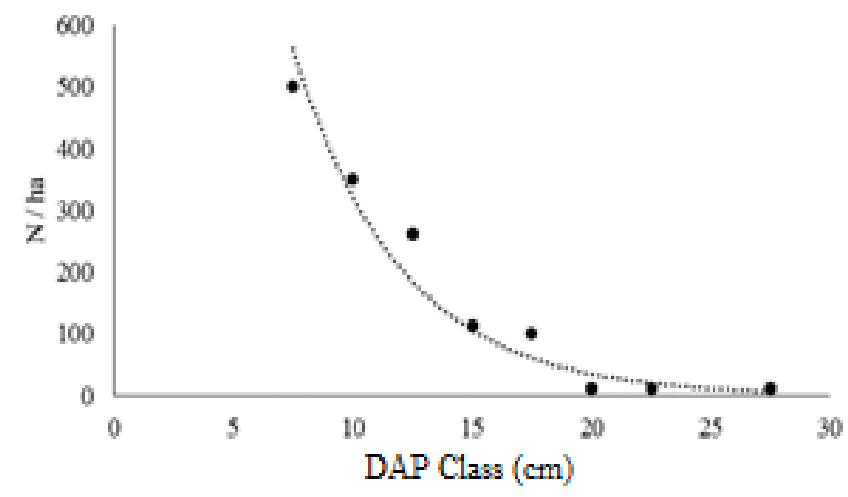

31

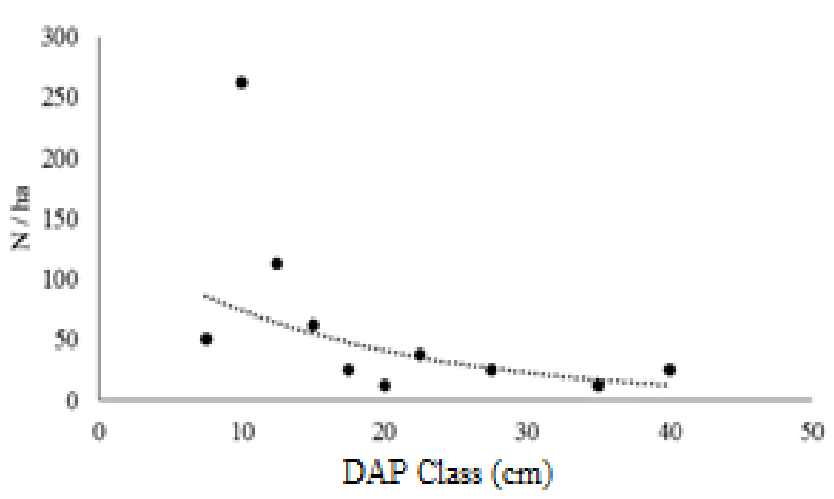

51

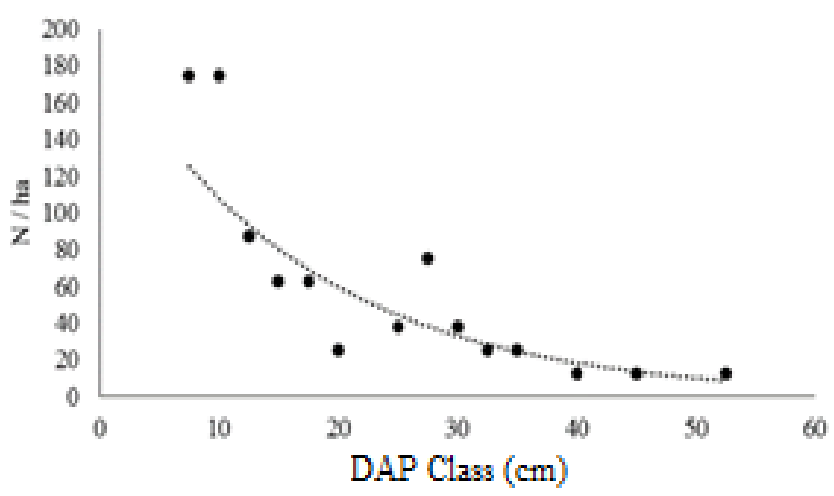

12

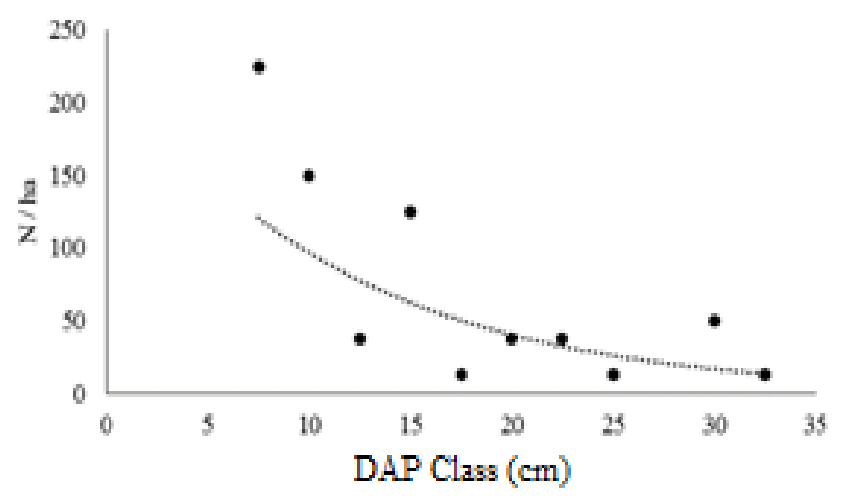

21

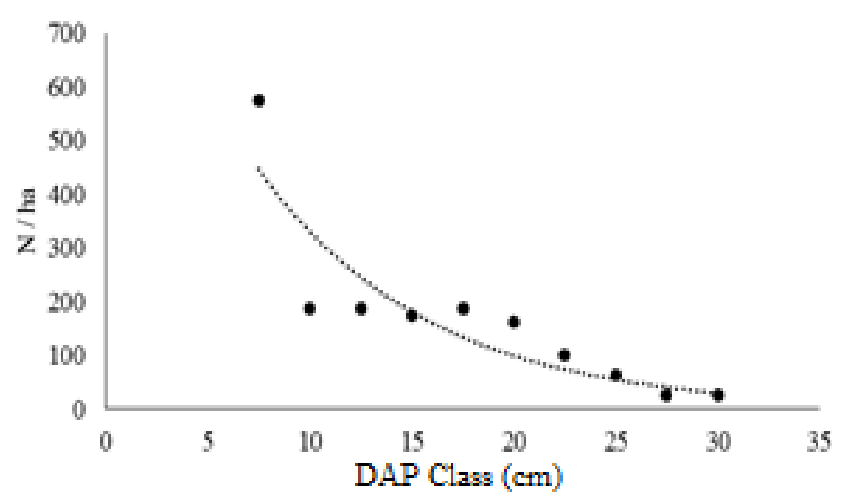

41

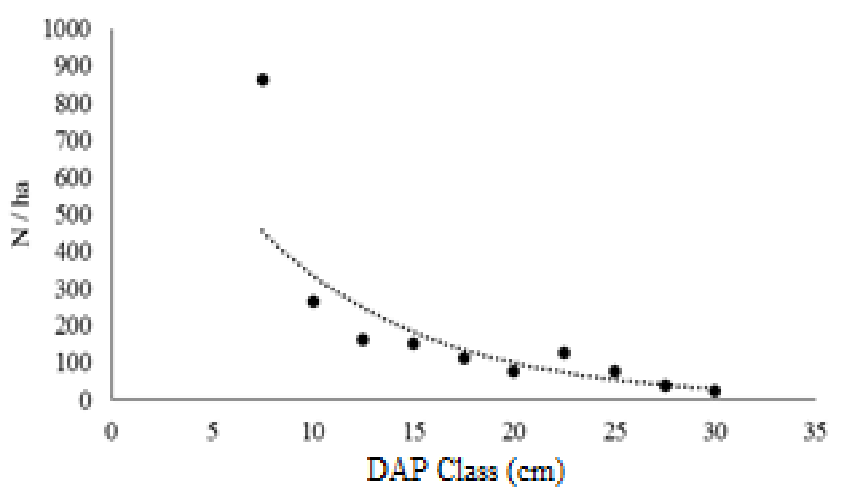

52

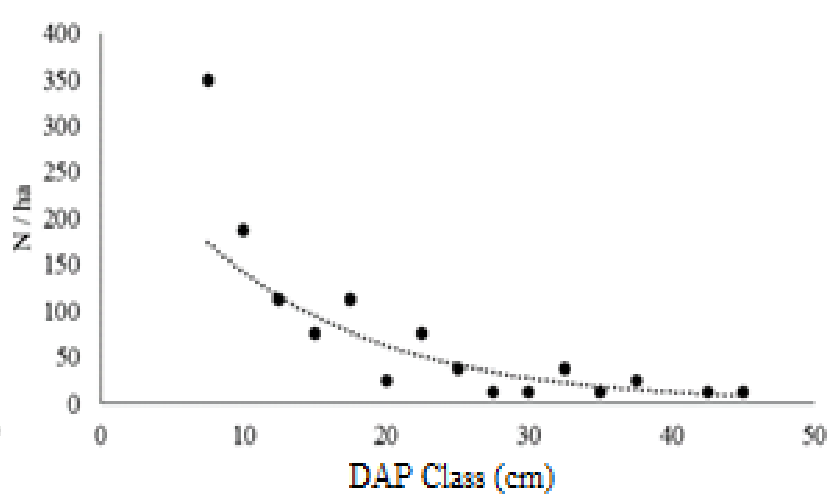


61

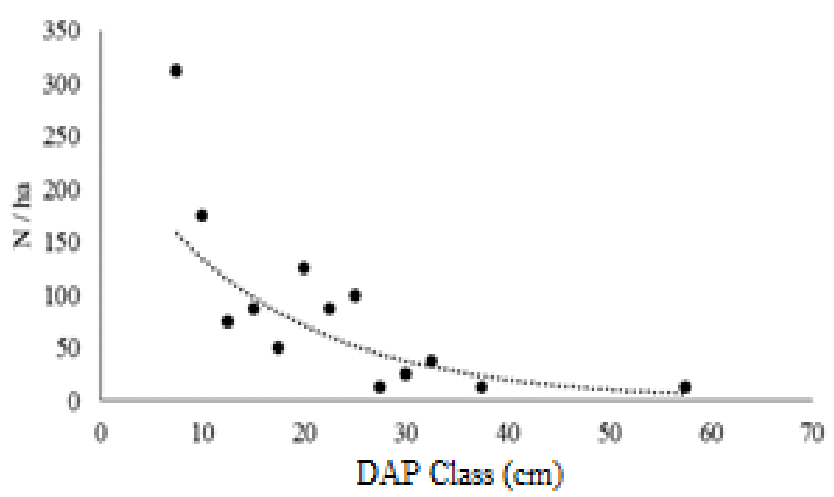

81

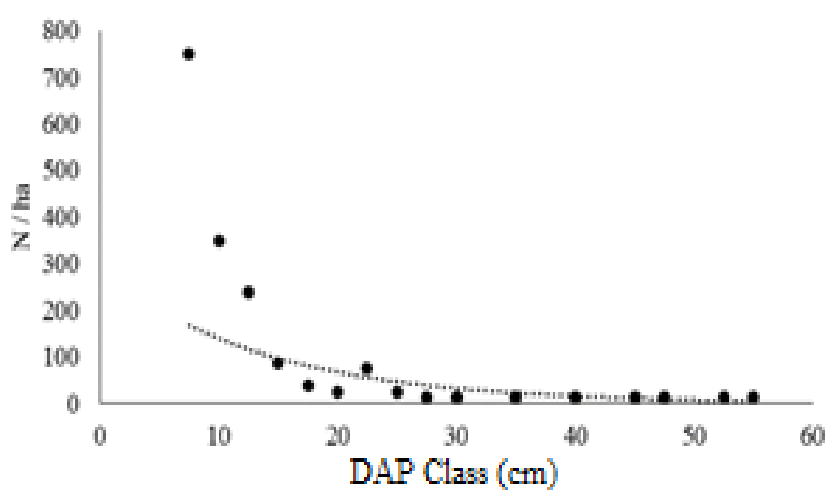

71

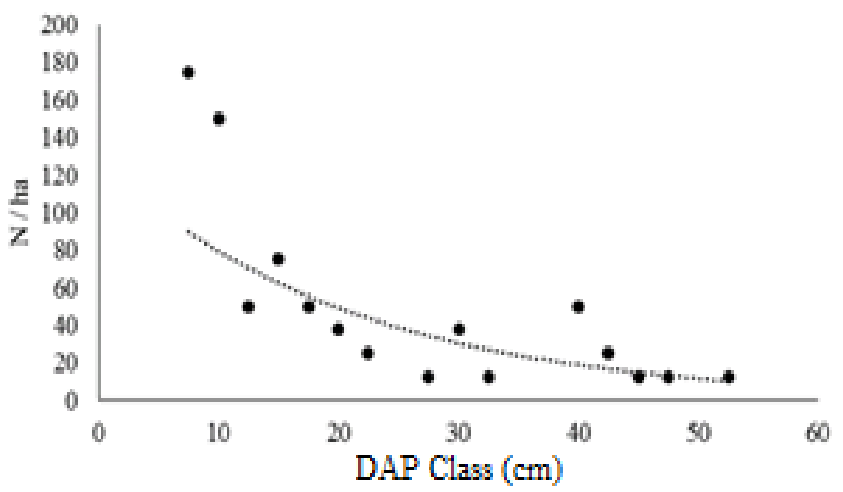

82

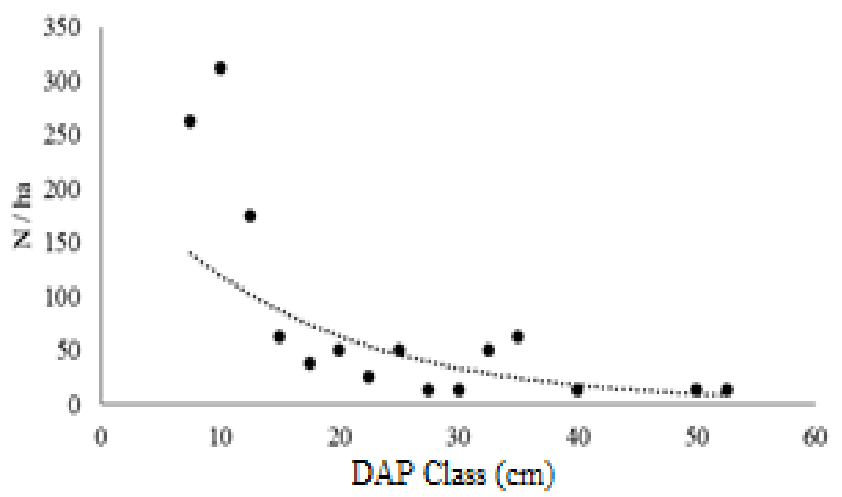

Fig. 3 Distribution of individuals by diameter classes (cm) in sites 11, 12, 13, 21, 31, 41, 51, 52, 61, 71, 81, 82 in 2015.

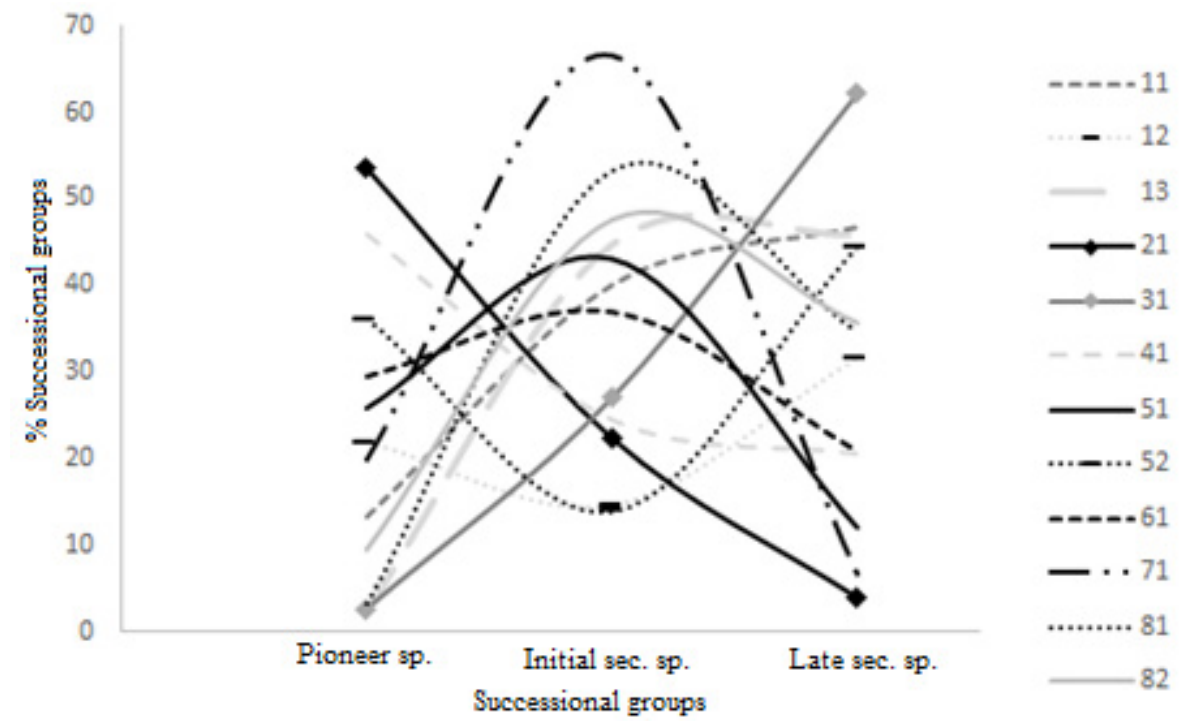

Fig. 4 Distribution of species by successional groups (ecologic).

groundwater in most favorable conditions in site 81 . It is likely that fertility indicators and groundwater are compensations, as observed at sites 31 and 81, which present low fertility, but good water supply, which may have led to a greater structure and diversity of the vegetation in those sites [33].

The growth dynamics variation of the forest was evaluated based on the results of environmental parameters and size classes. Fig. 5 shows the mortality, ingrowth, gain and loss rates of basal area among sites. 
The highest mortality rates occurred in $21,13,11,12$ and 71 sites. A fire affected site 21 in 2012, causing the highest mortality of trees. The 11, 12, 13, 71 sites are the group with the highest species dominance, and the site 71 presents characteristics of regeneration through clearings, with low tree density (D) (Fig. 6) and higher occurrence of tall individuals (not shown).

The lowest mortality rates occurred in 31,82 and 81 sites, which had the best values for canopy parameters (H, LAI, B) (Fig. 6).

Highest number of ingrowth occurred in 12 and 71 sites (Fig. 5). The 13, 81, 21, 82 and 31 sites presented the lowest values. The site 21 presented stagnation of growth caused by the fire. Regarding the site 13, a possible relationship between the lower growth rate and the higher tree density may be occurring.

Regarding the rate of gain in basal area, the site that obtained the highest gain was 12 (Fig. 5). Those with the lowest increment in basal area were 82, 81, 31, 61 and 13.

In relation to the loss rate of basal area, $31,81,82,12$ sites presented the lowest losses due to low tree mortality, while sites $11,13,51$ and 21 had the highest losses (Fig. 5).

The sites 31,81 and 82 present low mortality but low ingrowth while sites 11 and 12 present high mortality, but also high rates of ingrowth. Site 13, very similar to 11 , presents different behavior. The least dynamic sites are 31,81 and 82 , the most dynamic are $11,12,13,21$, 71 , and the moderately dynamic ones are $61,52,51$ and 41 (Fig. 6). These dynamics are represented by the magnitude of the growth parameters (ingrowth rate and rate of basal area gain), and the parameters of forest decline (mortality rate and loss rate in basal area).

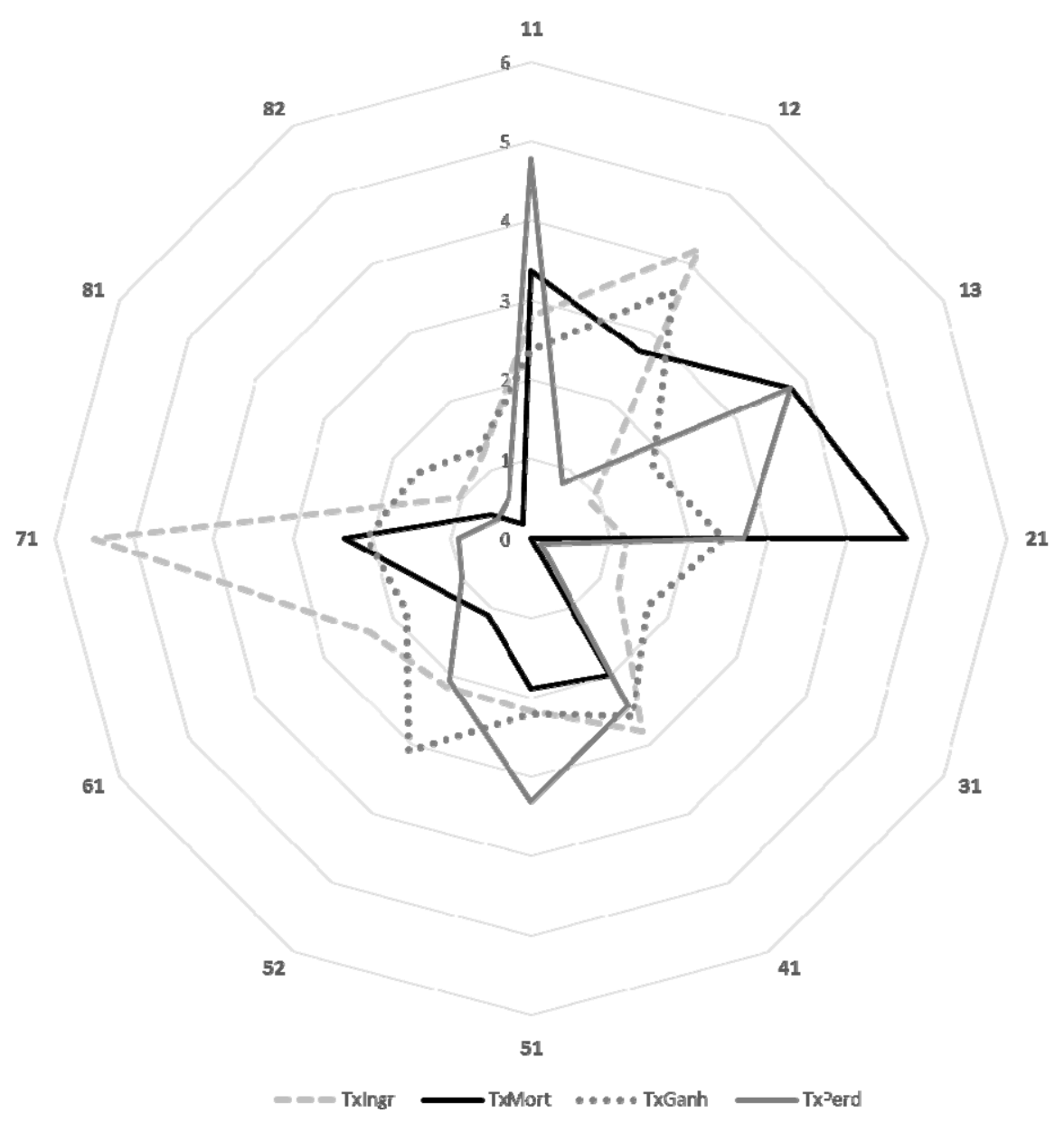

Fig. 5 Mortality rates, ingrowth, gain and lost between 2010 and 2015 for forest sites. 


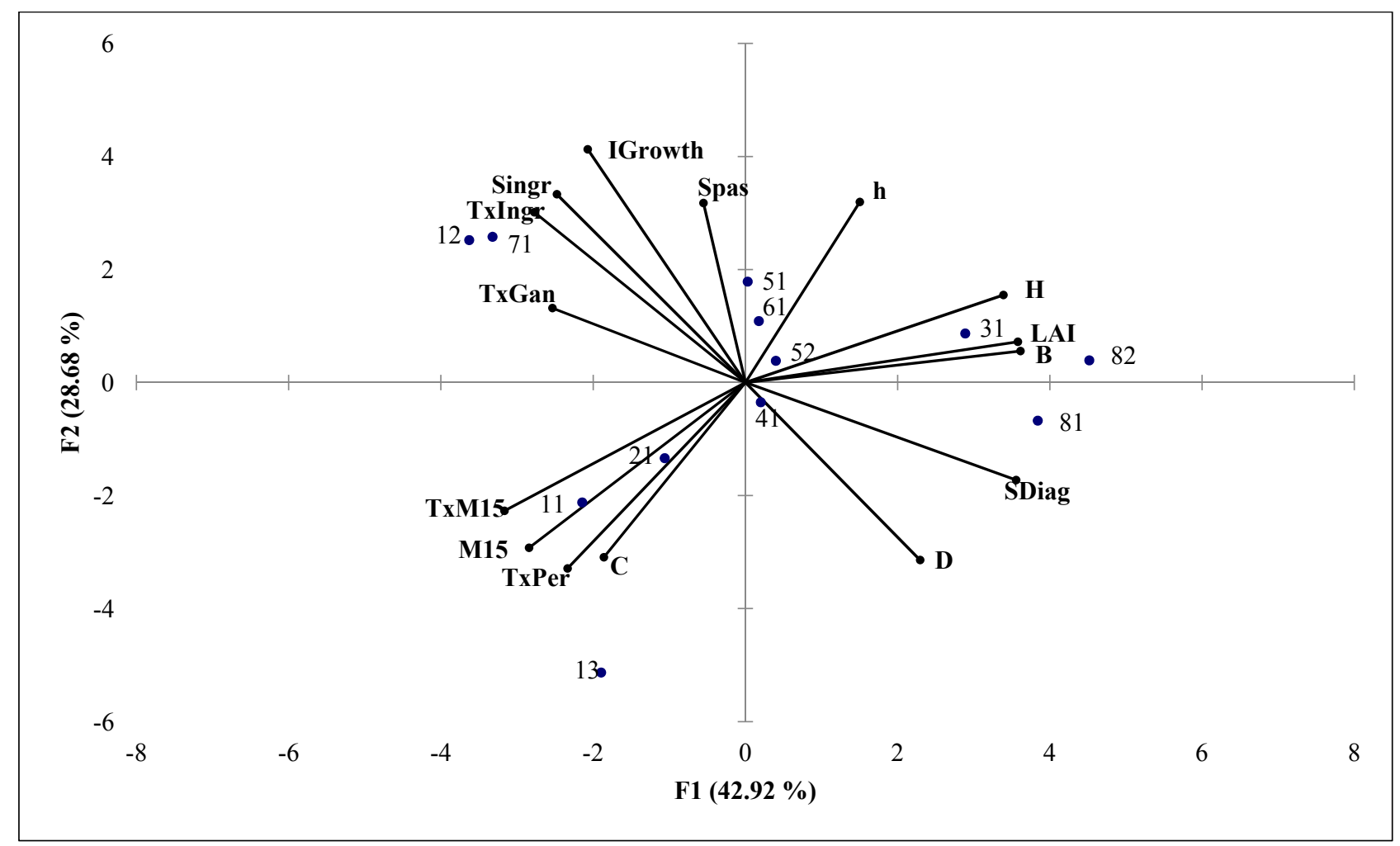

Fig. 6 Scattering of canopy parameters and forest growth, for the sites, between components 1 and 2 (F1 and F2) of PCA.

Table 2 Sum of trees on the diagonal (SDiag), number of dead trees between 2010 and 2015 (M15), sum of trees that changed class (SPas), sum of trees that entered the first diameter classes (Singr), indicator of growth dynamics 2015 referring to the initial period in 2010 (IGrowth).

\begin{tabular}{lllllll}
\hline Site & Tot. & SDiag & M15 & SPas & SIngres & IGrowth \\
\hline 11 & 86 & 47 & 11 & 12 & 9 & 0.36 \\
12 & 77 & 26 & 5 & 21 & 12 & 1.06 \\
13 & 119 & 71 & 20 & 17 & 4 & 0.23 \\
21 & 169 & 71 & 30 & 44 & 7 & 0.50 \\
31 & 51 & 33 & 0 & 13 & 3 & 0.48 \\
41 & 204 & 113 & 16 & 38 & 23 & 0.47 \\
51 & 75 & 38 & 5 & 22 & 7 & 0.67 \\
52 & 107 & 60 & 9 & 23 & 10 & 0.48 \\
61 & 111 & 62 & 6 & 25 & 11 & 0.53 \\
71 & 87 & 36 & 9 & 18 & 17 & 0.78 \\
81 & 151 & 101 & 5 & 29 & 6 & 0.35 \\
82 & 107 & 79 & 1 & 16 & 6 & 0.28 \\
\hline
\end{tabular}

The results of the application of the transition matrices to obtain the parameters for the growth dynamics indicator (ratio between the parameters of growth and decline) in the period from 2010 to 2015 were summarized on Table 2. The 12, 51 and 71 sites had higher values, whereas the sites 11, 13, 81 and 82 had the lowest values.

When analyzing the results of the indicator with the vectors and sites of Fig. 6 , authors will verify that it indicated sites with no relation to each other, referring to the regeneration stage and environmental parameters. The sites 11 and 13 are distinct of the 81 and 82 sites, as sites 12,51 and 71 are distinct too. Other variables, not addressed in this work, may be contributing to these results. In any case, this methodology has a logical principle. 
In Fig. 6, authors can see that sites 12 and 71 present the highest rates of gain and growth indicator, but with worse values for the canopy parameters, while sites 31 , 81 and 82 present higher canopy values, with low rates of growth and gain of basal area.
The sites 11 and 13 presented a high loss rate and a high dominance. The forest growth indicator indicated areas with less competition, as it is inversely proportional to the forest density (D), which in turn is inversely proportional to ingrowth (Table 7).

Table 3 Canopy and diversity parameters by site: leaf area index (LAI); average tree height (h); Density of individuals (D); Basal area (B); Shannon index (H'); Simpson's dominance index (C), measured in 2010.

\begin{tabular}{lllllll}
\hline Site & $\mathrm{LAI}\left(\mathrm{m}^{-2} / \mathrm{m}^{-2}\right)$ & $\mathrm{h}(\mathrm{m})$ & $\mathrm{D}\left(\right.$ ind. $\left./ \mathrm{m}^{2}\right)$ & $\mathrm{B}\left(\mathrm{m}^{2} \cdot \mathrm{ha}^{-1}\right)$ & $\mathrm{H}^{\prime}$ & $\mathrm{C}$ \\
\hline 11 & 3.7 & 8.7 & 0.10 & 17 & 2.31 & 0.11 \\
12 & 4.0 & 9.5 & 0.09 & 14 & 2.24 & 0.11 \\
13 & 3.8 & 8.4 & 0.15 & 15 & 1.88 & 0.19 \\
21 & 3.7 & 9.8 & 0.14 & 25 & 2.61 & 0.09 \\
31 & 5.9 & 9.7 & 0.12 & 26 & 2.60 & 0.09 \\
41 & 5.1 & 9.5 & 0.15 & 23 & 2.56 & 0.10 \\
51 & 4.4 & 11.1 & 0.09 & 26 & 2.64 & 0.07 \\
52 & 5.1 & 10.4 & 0.12 & 27 & 2.41 & 0.10 \\
61 & 4.2 & 10.8 & 0.09 & 20 & 2.47 & 0.09 \\
71 & 3.4 & 10.7 & 0.06 & 17 & 2.19 & 0.10 \\
81 & 5.3 & 9.2 & 0.18 & 32 & 2.87 & 0.07 \\
82 & 5.4 & 12.1 & 0.13 & 29 & 2.92 & 0.06 \\
\hline
\end{tabular}

Table 4 Relief and water proximity parameters: elevation, slope, orientation of the slope (aspect), distance of the water body (DstWat), elevation difference between the site and the water body (ElevWat).

\begin{tabular}{|c|c|c|c|c|c|}
\hline Site & Elevation (m) & Slope ${ }^{(0)}$ & Aspect & DstWat (m) & ElevWat (m) \\
\hline 11 & 818 & 7 & 15 & 150 & 30 \\
\hline 12 & 807 & 16 & 217 & 150 & 10 \\
\hline 13 & 825 & 6 & 289 & 150 & 10 \\
\hline 21 & 780 & 7 & 170 & 400 & 40 \\
\hline 31 & 759 & 7 & 95 & 0 & 2 \\
\hline 41 & 779 & 11 & 213 & 600 & 40 \\
\hline 51 & 710 & 8 & 77 & 600 & 40 \\
\hline 52 & 764 & 15 & 83 & 600 & 40 \\
\hline 61 & 725 & 10 & 128 & 600 & 40 \\
\hline 71 & 743 & 22 & 201 & 600 & 40 \\
\hline 81 & 701 & 6 & 30 & 150 & 8 \\
\hline 82 & 689 & 2 & 341 & 150 & 8 \\
\hline
\end{tabular}

Table 5 Soil classes and forest typology of sites.

\begin{tabular}{lll}
\hline Site & Soil Classe & Tipology by usual method [32] \\
\hline 11,13 & Oxisols & Deciduous \\
12 & ultisols & Deciduous \\
21 & Oxisols & Deciduous \\
31 & cambisols & Rain Forest \\
41 & ultisols & Semideciduous \\
51 & ultisols & Semideciduous \\
52 & ultisols & Semideciduous \\
61 & Humic Haplustox & Deciduous \\
71 & cambisols & Semideciduous \\
81 & cambisols & Rain Forest \\
82 & ultisols & Semideciduous \\
\hline
\end{tabular}


Table 6 Soil parameters (fertility and texture) of horizon $A$ in each site.

\begin{tabular}{|c|c|c|c|c|c|c|c|c|c|c|c|c|c|c|c|c|c|c|c|c|c|c|c|c|}
\hline Site & $\mathrm{H}_{\mathrm{H} 2 \mathrm{O}}$ & $\mathrm{P}$ & $\mathrm{K}$ & $\mathrm{Ca}$ & $\mathrm{Mg}$ & $\mathrm{Al}$ & $\mathrm{H}+\mathrm{Al}$ & SB & $\begin{array}{l}\text { CTC( } \\
\text { t) }\end{array}$ & $\begin{array}{l}\text { CTC } \\
\text { T) } \\
\end{array}$ & V & $\mathrm{m}$ & M.O. & $\mathrm{Zn}$ & $\mathrm{Fe}$ & Mn & $\mathrm{Cu}$ & Prof. & Casc. & $\begin{array}{l}\text { thin } \\
\text { land }\end{array}$ & $\begin{array}{l}\text { Thick } \\
\text { Sand }\end{array}$ & $\begin{array}{l}\text { Thin } \\
\text { Sand }\end{array}$ & Silt & Clay \\
\hline & & \multicolumn{2}{|c|}{$\mathrm{mg} \cdot \mathrm{dm}^{-3}$} & \multicolumn{7}{|c|}{-------------cmolc·dm ${ }^{-3}$--------------- } & \multicolumn{2}{|c|}{----\%--- } & $\mathrm{dag} \cdot \mathrm{kg}^{-1}$ & \multicolumn{4}{|c|}{$-----M g \cdot \mathrm{dm}^{-3}-----$} & $\mathrm{cm}$ & \multicolumn{6}{|c|}{---------------------\%o----------------- } \\
\hline $11 / 13$ & 5.6 & 5.2 & 104.7 & 9.1 & 0.8 & 0.0 & 6.0 & 10.1 & 10.1 & 16.1 & 62.1 & 0.0 & 9.3 & 2.2 & 19.2 & 179.0 & 0.3 & 16.7 & 0 & 100 & 10 & 5 & 15 & 70 \\
\hline 12 & 5.6 & 6.0 & 97.9 & 4.1 & 0.8 & 0.4 & 7.0 & 5.2 & 5.6 & 12.2 & 38.8 & 13.5 & 6.1 & 1.6 & 37.7 & 114.3 & 0.4 & 23.0 & 2 & 98 & 13 & 6 & 15 & 66 \\
\hline 21 & 5.2 & 3.3 & 61.5 & 0.9 & 0.2 & 1.1 & 8.6 & 1.3 & 2.4 & 9.9 & 11.7 & 53.7 & 4.5 & 0.6 & 64.9 & 11.8 & 0.9 & 20.8 & 3 & 97 & 9 & 4 & 17 & 71 \\
\hline 31 & 5.6 & 8.6 & 44.3 & 5.9 & 0.4 & 0.0 & 6.0 & 6.4 & 6.4 & 12.4 & 51.7 & 0.0 & 6.5 & 6 & 45.3 & 56.7 & 0.7 & & r & 93 & 20 & 4 & , & 67 \\
\hline 41 & 5.9 & 13.3 & 255.0 & 6.6 & 1.7 & 0.0 & 6.9 & 9.0 & 9.0 & 15.9 & 56.4 & 0.0 & 12.4 & 3.1 & 32.6 & 235.3 & 0.8 & 16.7 & 6 & 94 & 7 & 2 & 38 & 53 \\
\hline 51 & 5.7 & 5.3 & 81.8 & 6.4 & 1.4 & 0.6 & 6.9 & 8.0 & 8.6 & 14.9 & 50.3 & 16.0 & 8.8 & 4.5 & 35.4 & 82.4 & 1.0 & 24.8 & 40 & 60 & 6 & 2 & 40 & 52 \\
\hline 52 & 6.0 & 4.1 & 133.0 & 6.3 & 1.8 & 0.0 & 5.4 & 8.5 & 8.5 & 13.9 & 60.8 & 0.0 & 9.5 & 8.5 & 74.3 & 250.7 & 1.7 & 10.3 & 3 & 97 & 3 & 2 & 49 & 46 \\
\hline 61 & 5.1 & 4.7 & 86.2 & 2.9 & 0.3 & 2.1 & 11.4 & 3.5 & 5.5 & 14.8 & 19.1 & 59.2 & 8.9 & 0.9 & 51.9 & 24.8 & 0.2 & 27.9 & 54 & 46 & 13 & 3 & 13 & 71 \\
\hline 71 & 5.7 & 10.7 & 203.5 & 8.2 & 1.3 & 0.1 & 5.5 & 10.0 & 10.0 & 15.5 & 64.2 & 0.6 & 7.6 & 5.3 & 86.4 & 314.6 & 0.6 & 8.7 & 14 & 86 & 4 & 3 & 42 & 52 \\
\hline 81 & 4.9 & 5.5 & 112.2 & 1.4 & 0.7 & 1.5 & 8.5 & 2.3 & 3.9 & 10.8 & 19.5 & 47.1 & 5.6 & 1.3 & 77.7 & 100.9 & 0.8 & 19.7 & 64 & 37 & 21 & 7 & 33 & 40 \\
\hline 82 & 7.2 & 7.2 & 455.0 & 8.2 & 1.6 & 0.0 & 1.2 & 11.0 & 11.0 & 12.1 & 89.4 & 0.0 & 6.2 & 2.4 & 32.1 & 171.3 & 1.5 & 24.1 & 7 & 93 & 14 & 5 & 40 & 41 \\
\hline
\end{tabular}

Table 7 Pearson correlation between canopy and forest parameters in twelve sites. Values in bold are different from 0 with a significance level alpha $=0.05$.

\begin{tabular}{|c|c|c|c|c|c|c|c|c|c|c|c|c|}
\hline Var. & LAI & $\mathrm{h}$ & $\mathrm{D}$ & $\mathrm{B}$ & $\mathrm{H}^{\prime}$ & $\mathrm{C}$ & TxGan & TxPer & SDiag & M15 & SPas & SIngr \\
\hline $\mathrm{H}$ & 0.23 & & & & & & & & & & & \\
\hline $\mathrm{D}$ & 0.48 & -0.39 & & & & & & & & & & \\
\hline B & 0.75 & 0.40 & 0.52 & & & & & & & & & \\
\hline $\mathrm{H}^{\prime}$ & 0.66 & 0.51 & 0.35 & 0.88 & & & & & & & & \\
\hline $\mathrm{C}$ & -0.46 & -0.67 & 0.08 & -0.70 & -0.89 & & & & & & & \\
\hline TxGan & -0.28 & -0.24 & -0.26 & -0.38 & -0.35 & 0.16 & & & & & & \\
\hline TxPer & -0.50 & -0.43 & 0.02 & -0.34 & -0.42 & 0.48 & 0.19 & & & & & \\
\hline SDiag & 0.72 & 0.15 & 0.55 & 0.61 & 0.49 & -0.18 & -0.74 & -0.16 & & & & \\
\hline M15 & -0.78 & -0.48 & 0.01 & -0.50 & -0.62 & 0.64 & 0.28 & 0.73 & -0.49 & & & \\
\hline SPas & 0.01 & 0.24 & -0.34 & 0.11 & 0.16 & -0.36 & 0.40 & -0.28 & -0.54 & -0.17 & & \\
\hline SIngr & -0.40 & 0.16 & -0.76 & -0.51 & -0.34 & -0.07 & 0.49 & -0.15 & -0.64 & -0.04 & 0.19 & \\
\hline IGrowth & -0.28 & 0.25 & -0.71 & -0.30 & -0.15 & -0.23 & 0.57 & -0.28 & -0.77 & -0.12 & 0.77 & 0.77 \\
\hline
\end{tabular}


Loss rate in basal area seems to be related to the succession stage, due to its similar orientation and magnitude with species dominance, a situation found in the first stages of succession, by pioneer species and initial secondary species.

\section{Discussion}

Due to the relationships between environmental parameters, succession stages and site growth dynamics in the transition region (ecotone), it was verified that the factors influencing the forest's behavior are beyond the complexity. Anthropism can be an interference factor in these relationships, which is translated by the history of human interventions such as logging and, especially, fire. Using aerial photographs from 1964 (photography $n$. 11591/VM AST-10 1370PMW R-82 of 09.02.1964), authors observed that the remaining patches at that time were 2, 3, 4, 5, 7 and 8. Patch 6 was partially covered and patch 1 was fully covered by pasture or other agricultural activity. Therefore, authors estimated that parts of patches 1 and 6 are between 40 and 50 years old [33].

There are no historical records of anthropogenic interference in the natural environment. The reports are inaccurate, making it impossible to measure their influence on vegetation. All patches had traces of fire, some had small fragments of charcoal, bark or pieces of charred trunks in their first layers of soil, showing that fire has occurred at different times, but its intensity and scope could not be measured. The last fire was in September 2012 in patches 1 and 2, causing burning of litter, the base of some trees, lianas and dead trees, reaching the treetops. That fire induced strong leaf fall because of stress. At the end of the rainy season, in March 2013, few traces of fire were visible [33].

Although the effects of human impacts and environmental conditions could not be isolated to know their relationships on the current dynamic grown, the analysis showed an indicator which can be used to evaluate the dynamic grown of forests.

\section{Conclusion}

The contribution of this study was the proposition of a methodology to analyze the dynamics of forest growth, related to coverage and diversity parameters, and other factors that interfere in its development or decline.

An indicator of growth dynamics was proposed, but can not be said that it correlates with forest succession.

It was confirmed that the density factor interferes in growth dynamics of the forest.

The main limitations found in this study are due to anthropogenic actions over a long period, mainly fire, on which there is no precise record, which may be interfering in growth dynamics, environmental parameters and the succession of the forest.

\section{Acknowledgment}

This study is a result of project sponsored by $\mathrm{CNPq}$ 561864/2010-1 "Parameters of forest fragmentation as subsidy for the environment quality and recovery of degraded environments", with the support of Fapemig to trainee fellowships, Santo Agostinho Colleges and São João Del Rei University. Authors thank to Morgana Flávia Rodrigues Rabelo who helped on botanical identify, Leon Sulfierry, Douglas Paula Soares, Felipe Silva Guimarães and Dauler Perona Gomes, who helped in installation and measurements of data gathering of forest inventory, Renato Castro, Daniela Melo and Rafael da Silva by the suggestions in this work.

\section{References}

[1] Odum, E. P. 1988. Ecology. Rio de Janeiro: Guanabara.

[2] Guilherme, F. A. G. 1999. Effects of the Flood Regime and Bamboo on the Dynamics of the Tree Community of a Semideciduous Forest Fragment in the South of Minas Gerais. Master's Dissertation in Forest Engineering, Federal Lavras University.

[3] Higuchi, I. G., and Higuchi, N. 2004. The Amazon Forest and its Multiple Dimensions: A Proposal for Environmental Education. Manaus: INPA. 
[4] Gomide, G. L. A. 1997. Structure and Dynamics of Growth of Primary and Secondary Tropical Forests in the State of Amapá. Master's Dissertation in Forest Engineering, Federal University of Paraná.

[5] Sampaio, E. V. S. B. 2003 "Characterization of the Caatinga and Environmental Factors which Affect the Ecology of Woody Plants." Brazilian Ecosystems: Management and Conservation. Fortaleza: Graphic Expression and Publisher: 129-42.

[6] Silva, V. S. M. 2006. Management of Native Forests: Planning, Implementation and Monitoring. Cuiabá: Federal University of Mato Grosso.

[7] Gaspar, R. O. 2013. Classification of Successional Stages, Stock and Growth of Carbon in Semideciduous Seasonal Forest, Vale do Rio Doce, MG. Ph.D. Thesis in Federal Viçosa University.

[8] Sanquetta, C. R., Ângelo, H., Brena, D. A., and Mendes, J. B. 1994. "Prediction of Diametric Distribution, Mortality and Ingrowth of Natural Forest with Markovian Power Matrix." Revista Floresta 24 (1/2): 23-36.

[9] Pulz, F. A., Scolforo, J. R. S., Oliveira, A. D., Mello, J. M., and Oliveira Filho, A. T. 1999. "Accuracy of the Diametric Distribution of an Inequal Ages Forest with the Transition Matrix." Cerne 5 (1): 1-14.

[10] Flora do Brasil 2020. 2016. "Botanical Garden of the Rio de Janeiro." Accessed September 28, 2016. http://floradobrasil.jbrj.gov.br.

[11] Shugart, H. H., and West, D. C. 1981. "Long-term Dynamics of Forest Ecosystems: Computer Simulation Models, which Allow for Numerous Seedlings and the Long Lives of Large Trees, Predict how Forests will Respond to Different Management Techniques." American Scientist 69 (6): 647-52.

[12] Pantaleão, J. C., Soares, T. S., Colpini, C., and Matricardi, W. A. T. 2008. "Evaluation of Structure, Growth, Mortality and Ingrowth in a Submontana Semidecidual Forest of the Amazon in Mato Grosso." Amazônia: Ciência \& Desenvolvimento 4 (7).

[13] Enright, N., and Ogden, J. 1979. “Applications of Transition Matrix Models in Forest Dynamics: Araucaria in Papua New Guinea and Nothofagus in New Zealand." Austral Ecology 4 (1): 3-23.

[14] Schaaf, L. B., Figueiredo Filho, A., Galvão, F., and Sanquetta, C. R. 2006. "Change in the Diametric Structure of a Mixed Ombrophilous Forest in the Period between 1979 and 2000." Revista Árvore 30 (2): 283-95.

[15] Morrison, D. F. 1976. Multivariate Statistical Methods. New York: McGraw-Hill.

[16] Bierzychudek, P. 1982. "The Demography of Jack-in-the-Pulpit, a Forest Perennial that Changes Sex." Ecological Monographs 52 (4): 335-51.

[17] Teixeira, L. M., Chambers, J. Q., Higuchi, N., Lima, A. J.
N., Carneiro, V. M. C., Dos Santos, J., et al. 2007. "Projection of the Terra firme Natural Forest Dynamics, Region of Manaus-AM, Using the Probabilistic Transition of Markov Chain.” Acta Amazonica 37 (3): 377-84.

[18] Shugart, H. H. 1984. A Theory of Forest Dynamics: The Ecological Implications of Forest Succession Models. New York: Springer-Verlag.

[19] Alder, D. 1980. "Forest Volume Estimation and Yield Prediction. v.2-Yield Prediction. Rome: FAO." FAO Forestry Paper 22 (2).

[20] Cubas, R., Watzlawick, L. F., and Figueiredo Filho, A. 2016. "Increment, Ingrowth, Mortality in a Fragment of Mixed Ombrophilous Forest in Three Bars-SC." Ciência Florestal 26 (3): 889-900.

[21] Colpini, C., Silva, V. S. M., Higuchi, N., Travagin, D. P., and Assumpção, J. V. L. 2010. "Increment, Ingrowth and Mortality in an Open/Seasonal Ombrophilous Contact Forest in Marcelândia, Mato Grosso State." Acta Amazonica 40 (3): 549-56.

[22] Sheil, D., and May, R. M. 1996. "Mortality and Recruitment Rate Evaluations in Heterogeneous Tropical Forests." Journal of Ecology 84 (1): 91-100.

[23] IBGE, D. D. G. 1993. "Vegetation Map of Brazil." Rio de Janeiro: $I B G E$.

[24] Peel, M. C., Finlayson, B. L., and Mcmahon, T. A. 2007. "Updated World Map of the Köppen-Geiger Climate Classification." Hydrology and Earth System Sciences Discussions 4 (2): 439-73.

[25] Gomide, R. L., Albuquerque, P. E. P., Andrade, C. L. T., Durães, F. O. M., and Viana, J. H. M. 2006. "Climatic Characterization and Determination of the Water Requirement of Crops of the Sete Lagoas Precision Site for the Phenotyping of Genotypes of Drought Tolerant Cereals." Alice Repository. Accessed October 30, 2016. http://www.alice.cnptia.embrapa.br/handle/doc/490096.

[26] Virtual Herbarium Tropicos.org. 2016. "Missouri Botanical Garden.” Accessed May 29, 2015. http://www.tropicos.org.

[27] The Field Museum. 2016. "Neotropical Herbarium Specimens 1999-2016." Accessed May 29, 2015. http://fm1.fieldmuseum.org/vrrc/.

[28] Angiosperm Phylogeny Group. 2009. "An Update of the Angiosperm Phylogeny Group Classification for the Orders and Families of Flowering Plants: APG III." Botanical Journal of the Linnean Society 161 (2): $105-21$

[29] The New York Botanical Garden. 2007. "International Plant Science Center.” The C. V. Starr Virtual Hebarium. Accessed September 29, 2016. htpp://sciweb.nybg.org/Science2/vii2.asp.

[30] Higuchi, P., Oliveira Filho, A. T., Silva, A. C., Machado, 
E. L. M., Santos, R. M., and Pifano, D. S. 2008. "Dynamics of the Tree Community in a Fragment of Seasonal Semideciduous Montana Forest in Lavras, Minas Gerais, in Different Classes of Soils." Revista Árvore 32 (3): 417-26.

[31] Meyer, H. A. 1952. "Structure, Growth, and Drain in Balanced Uneven-Aged Forests." Journal of Forestry 50 (2): 85-92.

[32] Costa, T., Silva, A. F., Oliveira, L. M. T. D., and Viana, J. H. M. 2015. "Probabilistic Classification of Tree and
Shrub Vegetation on Phytogeographic System." Journal of Environmental Science and Engineering B 4 (6): 315-30.

[33] Costa, T. C. C., Fidalgo, E. C. C., Raid, M. A. M., Ribeiro, J. L., Viana, J. H. M., Ferreira, F. N., et al. 2016. "Forest Patch Conservation Indicators." Applied Ecology and Environmental Research 14 (3): 711-34.

[34] USDA. 1999. "Soil Taxononmy-a Basic System of Soil Classification for Making and Interpreting Soil Survey." 2nd. Washington: USDA. Soil Survey Staff. 